\title{
THE SYNTAGMA MUSICUM IN LUTHERAN ORGAN SERMONS OF THE SEVENTEENTH AND THE EIGHTEENTH CENTURIES
}

\author{
LUCINDE BRAUN \\ Universität Regensburg, Institut für Musikwissenschaft
}

\begin{abstract}
Izvleček: Razprava na podlagi zbirke orgelskih pridig analizira teološko recepcijo Praetoriusovega dela Syntagma musicum. Že leta 1621 je ta traktat prvič uporabil luteranski pastor. 1624 je traktat spodbudil Conrada Dietericha, da je v svojo pridigo vključil tudi opis orgel $v$ Ulmu. Po tridesetletni vojni je delo Michaela Praetoriusa redno nastopalo $v$ znanstvenem aparatu pridig. Modeli pridig in homiletični priročniki so pripomogli koblikovanju značilne glasbeno-teološke razprave. Kot primer medkulturne izmenjave zaslužijo posebno pozornost številni Praetoriusovi prevodi odlomkov iz dela Il Transilvano Girolama Dirute.
\end{abstract}

Ključne besede: orgelska pridiga, dispozicija orgel, glasbeno zgodovinopisje, teologija, glasbena misel, Michael Praetorius, Conrad Dieterich, Hieronymus Theodoricus, Girolamo Diruta

\begin{abstract}
Based on a corpus of organ sermons, this paper analyses the theological reception of the Syntagma musicum. As early as 1621 Michael Praetorius's treatise was explored for the first time by a Lutheran pastor. In 1624, it stimulated Conrad Dieterich to include a description of the Ulm organ into his sermon. After the Thirty Years' War Michael Praetorius's work became a regular part of the scholarly apparatus of the sermons. Model sermons and homiletic handbooks helped to shape a distinctive musical-theological discourse. As an example of intercultural exchange the transmission of several excerpts from Girolamo Dirutas Il Transilvano translated by Michael Praetorius merits special attention.
\end{abstract}

Keywords: organ sermon, organ disposition, historiography of music, theology, musical thought, Michael Praetorius, Conrad Dieterich, Hieronymus Theodoricus, Girolamo Diruta

The Syntagma musicum of Michael Praetorius has never fallen into oblivion. ${ }^{1}$ Johann Gottfried Walther, in his Musicalisches Lexicon, was one of the first commentators to devote entire pages - in his case, almost four - to its three extant volumes. ${ }^{2}$ How did such a continuous transfer of knowledge come about? And who - apart from the early forerunners of our musicological discipline - were the readers of Praetorius's treatises?

Let us begin by taking a look at Praetorius himself. It is well known that he allocated the three volumes of his Syntagma musicum to different groups of readers. The first

1 I would like to express my gratitude to Constanze Braun for the translation of this paper and to Michael Talbot who offered his help to create a readable English text.

2 Walther, Lexicon, 492-495. 
volume, which required a command of Latin, lists in its dedication "Episcopi, Abbates, Patres, Praepositi, Canonici, Doctores, \& Ecclesiarum Inspectores", ${ }^{3}$ thereby taking into account the contemporary representatives of the clergy in the territories of Saxony and Brunswick, Praetorius's sphere of activity. The title of the second volume includes the phrase "Not only for organists, instrumentalists, organ builders and all those attached to music [...] but also for philosophers, philologists and historians". ${ }^{4}$ Praetorius comes back to the second of these groups in that volume's preface by referring to it as a category of academically qualified readers who could improve and critically investigate the presented facts. ${ }^{5}$ The third volume addresses in its dedicatory matter "musicians, conductors and phonasci of the German nation". ${ }^{6}$

My contribution will deal neither with "Musicis" and "Phonascis" nor with "Organisten" and "Instrumentisten", but solely with the clergy. The research project "German Organ Sermons from 1600 to 1800 " at the University of Regensburg offers new material towards this end. ${ }^{7}$ The core objective of this project is to edit a corpus of about seventy surviving organ sermons on an online platform. ${ }^{8}$ The authors of these texts are German pastors, predominantly of the Lutheran confession, who in their sermons not only justify the purchase of a church organ, but also present a more complex, theologically based argument for the legitimacy of instrumental music within the Protestant service. ${ }^{9}$ In this context, reference to music-making in the Old Testament acquires a relevance equal to that of the early history of the organ in Christian Western Europe.

Earlier studies of these organ sermons have already demonstrated that Praetorius's Syntagma musicum was a seminal text for the preachers. ${ }^{10}$ In the course of our editorial work this conclusion has come even more to the fore. It turns out that twenty-nine organ

3 Praetorius, Syntagma musicum I, a2v.

4 "Nicht allein Organisten/ Jnstrumentisten/ Orgel= vnd Jnstrumentmachern/ sampt allen den Musis zugethanen [...] sondern auch Philosophis, Philologis vnd Historicis." Praetorius, Syntagma musicum II, title page.

5 "Kan auch gern geschehen lassen/ das hiernechst andere vnd vortrefflichere Leute/ welche sich viel Jahre in den Antiquiteten nicht allein der Musicorum, sondern auch Historicorum vnd Philosophorum ziemlich weit vmbgesehen/ daher Vrsach nemen/ diese schlechte delineationes vnd geringe Anleitung mercklichen zu verbessern/ auch deutlicher vnd vollkommener an Tag zu bringen." Ibid., [dedicatory texts], fol. 7v.

6 "[...] Musicis, Capellmeistern vnd Phonascis Teutscher Nation". Praetorius, Syntagma musicum $I I I$, [dedicatory texts], fol. $7 \mathrm{v}$.

7 The project "Deutsche Orgelpredigtdrucke zwischen 1600 und 1800 - Katalogisierung, Texterfassung, Auswertung", under the supervision of Katelijne Schiltz, is based at the Institute of Musicology of the University of Regensburg and supported by the Deutsche Forschungsgemeinschaft (DFG). I would like to express my gratitude to Katelijne Schiltz for the idea to undertake this case study and for the feedback she has given on my article.

8 The commentated full-text editions of all the sermons mentioned here will be published on the digital platform https://orgelpredigt.ur.de/. In its current state this already provides a complete list of titles and a vast amount of background information on the authors of the sermons and the inaugurated instruments.

9 For a general introduction, see Braun, "Die Orgelpredigt"; Davies, "Kirchen Cron or Baalsfeldzeichen?", 326-336.

${ }^{10}$ Sato, "Theologische Disputationen", 104; Braun, "Die Orgelpredigt", 9-12. 
sermons mention Praetorius either directly or rely implicitly on his information. ${ }^{11}$ This proves that the Syntagma musicum was by no means read only by professional musicians. A considerable segment of Praetorius's readership indeed comprised theologians, just as he had intended. All the pastors we are talking about had graduated from universities. Many of them held a master's or doctor's degree, some having attained the rank of superintendent or court chaplain, whereas others were simple incumbents of a pastorate who had strong literary ambitions. None of them had ever been an organist, cantor or organ builder during the course of their career. They belonged, rather, among the "Philosophis, Philologis and Historicis", since the indicated disciplines were occupied by theologians in Post-Reformation Germany. ${ }^{12}$ Which volumes of the Syntagma musicum were consulted most? The third volume, with its focus on questions regarding musical practice, was apparently altogether irrelevant for theologians. It is surprising, however, that the first volume of the treatise is cited only in exceptional cases, ${ }^{13}$ even though it had been written expressly for churchmen. Although the preachers possessed a knowledge of Latin, they apparently had no intention to flaunt their scholarship. It was much more important for them to reach a wide readership, be it via the church pulpit or via the published sermon. It comes as no surprise, then, that the majority of the authors refer for preference to the second volume of the Syntagma musicum, a book that was accessible to the audience of the sermons in their mother tongue.

The focus of the second volume is on organography. The emergence of interest in the history of organs and musical instruments, typical of the Early Modern Age, receives confirmation from an analysis of the organ sermons. When looking at the earliest of these texts, which date from between 1598 and 1615, one observes that the authors are already dealing with questions that would slightly later become pivotal in Praetorius's Organographia. In the sermons we encounter the ever-recurring question of how and when the organ was invented and introduced into church music. The theologians relied on the same sources that Praetorius would come to consult after them. From the Carolingian chronicles published by Johannes Aventinus they summoned up information about the organ that the emperor Constantine of Byzantium presented to Pepin (Johannes Lang, Nicolaus Polantus, Christoph Frick, Christoph Schultetus). They came across the report concerning the priest George of Venice, who had built an organ for Louis the Pious (Lang). Just like Praetorius, they took an interest in Pope Vitalian, who allegedly introduced the organ into the Roman liturgy as early as the seventh century (Lang, Georg Anwander). ${ }^{14}$ In similar vein to Praetorius, the theologians developed a purely Christian-oriented

${ }^{11}$ A complete list of the prints is added to this article in the Bibliography under: 1. Organ sermons quoting Praetorius.

12 Warnke, Die Theologen und die Technik.

${ }^{13}$ Theodoricus, Corona templi, K2v; Dieterich, Vlmische Orgel Predigt, 20; Sagittarius, Das dem Allmächtigen, 30.

${ }^{14}$ See the critical discussion of different sources in Praetorius, Syntagma musicum II, 90. Praetorius made an error when he assigned the pontificate of Vitalian to the reign of Constantine III of Byzantium. In some instances, this mistake provides a hint that a later author borrowed his information about Vitalian from Praetorius rather than from another book. 
historiography of music that excluded ancient sources altogether, whether of a historical or a music-theoretical nature. ${ }^{15}$

Praetorius presents the above-mentioned stages of organ history in a much more detailed way in the second chapter of part three of his Organographia ("In which time approximately and by whom the old organs have been invented") ${ }^{16}$ Ministers, who up till 1619 had been forced to select noteworthy facts about this "exotic" topic from chronicles and history books, ${ }^{17}$ now had the possibility of extracting the information from a single book. ${ }^{18}$ Moreover, in Praetorius's treatise the entire subject was - according to the state of academic knowledge at the time - profoundly and accurately discussed. This enabled ministers to refer their readers, whom they did not wish to trouble with a plethora of details, to the marginal annotations where Praetorius's volumes are cited. ${ }^{19}$ By this means, the more educated readers were enabled to consult the Syntagma musicum in order to learn more about the fascinating new "music machines".

The technical details about the history of organ-building that were expounded in the following chapters (nos. 3-4) of Organographia did not attract any comparable interest. ${ }^{20}$ However, Praetorius generated an important impulse via his organological descriptions. The idea of providing documentation for a newly built organ in conjunction with a printed organ sermon had not previously been entertained. The first organ specification embedded within an organ sermon was published in the Vlmische Orgel Predigt by Conrad Dieterich in 1624. This addition is in direct response to chapter 5 of Organographia, volume 2: "Containing dispositions of several noble organs in Germany". ${ }^{21}$ After outlining the history of organ-building, Dieterich introduces the new topic as follows:

Among other illustrious organs in Germany, twenty-three of which have been meticulously described by Michael Praetorius, there are two magnificent organs at Ulm. They were erected 136 years ago, when the cathedral of Ulm was built. The larger one was suspended above, between this pulpit and the choir; the smaller one stood in the choir. Both were destroyed in the Calvinist storm that befell this cathedral, when images, altars and organs were abolished. The present organ was built subsequently. ${ }^{22}$

15 The genesis of a Protestant, bible-oriented historiography of music has recently been examined in Schabram, "Ursprung und Entwicklung der Musica sacra". Despite the similarity of their goals and methods, it is obvious that the authors of organ sermons were unacquainted with these earlier historiographic attempts dating back to the sixteenth century.

${ }^{16}$ Praetorius, Syntagma musicum II, 89-93.

${ }^{17}$ See Braun, "Orgelpredigtdrucke in Regensburger Bibliotheken", 223-227; Kelber, "Leviathan".

${ }^{18}$ Explicit reference to Praetorius's account of the history of organs occurs in: Theodoricus, Corona templi, K2v; Dieterich, Vlmische Orgel Predigt, 20-21 and 23; Gerlach, ОРГАНОАОГІ ГМОГ, E1r-E1v; Münstermann, "Christliche Orgel-Predigt", 387-388; Vetterlein, Geistlich- und Gott wohlgefälliges Lob- und Danck-Opffer, 19-20; Richter, Vivum Dei Organum, 32; Skubowius, Daß durch ein wohleingerichtetes Orgelwerck, 21.

${ }^{19}$ An instructive analysis of the transformations sermons underwent after being prepared for print is offered in Rigney, "Sermon into Print".

${ }^{20}$ The sole exception is Roscher, Organum mysticum, 35. This author attempts to explain to his parishioners the term "ganze Orgel", drawing on Praetorius, Syntagma musicum II, 105 and 123.

${ }^{21}$ Praetorius, Syntagma musicum II, 161.

22 "Vnder andern vornehmen berühmbten Orgelwercken aber Teutscher Nation, deren dann 
By describing at length the building history, size and disposition of the enlarged Ulm instrument, Dieterich fills in a gap in Praetorius's work, for the latter had begun his list of organs, opening with the two famous monumental examples of Constance (Costnitz) and Ulm, with a confession that he could not find any information about their present state "despite my greatest efforts". ${ }^{23}$ At the end of his excursus about the Ulm Minster organ Dieterich enters into a renewed dialogue with Praetorius:

So our Organ is an instrument that one cannot find anywhere else in Germany; that can compete honourably with the noblest organs and would merit if not the first place, than the next to it. Recently, the highly renowned musician and organist Michael Praetorius has accorded this honour to the Ulm organ, preferring to it only the organ of Constance. But I am confident that he would alter his opinion if he could compare the two instruments by personal examination: he would then give preference to our organ here. The final judgement about this matter belongs to Praetorius and other specialists. For those who desire a more detailed account of organs and other musical instruments, I recommend his Syntagma musicum. ${ }^{24}$

Whether the instrument in the Ulm minster actually exceeded in size the legendary Constance organ, is not relevant here. Dieterichs's intention is clear: to demonstrate the superiority of his local organ via an impressive array of dimensions and numbers. This obscured the fact that the over three thousand pipes in Ulm corresponded exactly to the information given in Syntagma musicum for the organ of Constance, and that the forty organ stops of the Ulm organ were actually considerably fewer than the seventy that Praetorius had attributed to the other instrument.

The list of specifications in the Organographia served as a source for eleven further sermon authors, partly in order to provide a basis of comparison for an instrument built in their own home town, and partly to enable reference to famous examples of the art of

Michael Praetorius drey vnd zwaintzig vmbständiglich beschreibet/ sind auch vor Hundert vnd sechs vnd dreysig Jahrn/ so bald diß vnser Münster verfertiget/ zwo herrliche Orgeln darinn auffgerichtet/ deren die eine/ die grössere/ oben zwischen dieser Cantzel vnnd Chor hinauff/ die andere kleinere im Chor gestanden/ welche aber/ da der Calvinische Sturmgeist/ hinder vnser Münster kommen/ beneben den Bildern vnd Altären vmbgerissen vnd abgeschaffet worden. Darauff dann nachgehends/ diese jetzige newe Orgel erstens auffgerichtet." Dieterich, Vlmische Orgel Predigt, 23-24.

23 “[...] wie sehr ich mich auch darnach bemühet.” Praetorius, Syntagma musicum II, 161-162.

24 "Daß also diese vnser Orgel ein solch Werck/ dergleichen wol in Teutschland nicht so bald zufinden: welches auch mit denen Orgelwercken/ so die vornembsten darinn geachtet/ mit allen Ehren vmb den Vorzug concertiren vnd streiten kan; in gleichem/ wo nicht den ersten/ dennoch den nächsten Stand nach dem ersten/ darvon tragen wird. Gestalt dann der weit berühmbte Musicus vnd Organist/ Michaël Praetori[us], jhr denselben vorlängst deputieret/ in dem er deren nur allein die Costnitzer vorgezogen. Doch stehe ich noch an/ ob er nit/ wann er bey beyden den Augenscheyn selbst einnehmen solte/ Er seine Mainung ändern/ vnnd diese vnserige Orgel auch der costnitzer selbsten vor ziehen werde/ welches Judicium vnd Vrthail/ doch Jch jhme vnd andern Orgelnverständigen billich vberlassen/ vnd die so/ weitläuffrigern eygentlichern Bericht/ von Orgeln vnd andern Musicalischen Jnstrumenten begehren/ hiemit auff sein Syntagma musicum gewisen haben wil.” Dieterich, Vlmische Orgel Predigt, 26-27. 
organ building in general. ${ }^{25}$ Praetorius's references to unusually precious organs made of glass (Venice) or alabaster (Mantua) ${ }^{26}$ were also particularly well received. ${ }^{27}$

The idea of ennobling "the king of instruments" by way of an organological description was not at all common in Praetorius's time, as an almost contemporary organ sermon can illustrate. In 1628, four years after the Ulm sermon by Dieterich, Christoph Schultetus added a "Short description of the organ" to his sermon for the consecration of the organ in the St. Jakobi cathedral of Stettin. ${ }^{28} \mathrm{He}$, too, draws attention to the size of the instrument, but since he never mentions Praetorius we may assume that he had no knowledge of the Syntagma musicum. All the more interesting, then, is the justification he makes at the beginning of his description of this organ:

In histories it is not fitting to write about slight or poor things. They deal only with topics that are noteworthy [...]. An Aristarchus would mock me on account of my writing about organ-building, for organs are not judged important enough to be worth of record. We readily admit that it is not seemly to note down such slight things in universal history or other great historical treatises such as the one by Marcellinus (quo nemo melius magnitudinem Rom[anorum] descripsit). But those who relate the history of a town have not been deterred from writing about lesser things such as, for example, noble buildings. And there are several men who have published descriptions devoted exclusively to such buildings. Therefore, it is not entirely blameworthy if we add here a short description of our organ. For we hope, that, if not other readers, then at least the inhabitants of this city will deem it not unworthy of record. ${ }^{29}$

${ }^{25}$ Cf. Theodoricus, Corona templi, K4r; Peisker, Stolpenische Ehren-Crone, 47; Olearius, Encoenia HierOrganica, A4r, B4r; Münstermann, "Christliche Orgel-Predigt", 388; Olearius, Das fröliche Hallelujah, D1r; Vetterlein, Geistlich- und Gott wohlgefälliges Lob-und Danck-Opffer, 20; Roscher, Organum Mysticum, 8; Sagittarius, Das dem Allmächtigen, 30; Feuerlein, Schuldiges Lob Gottes, 13-14; Reichmann, "Organi laudes”, 197; Richter, Vivum Dei Organum, 33-34.

${ }^{26}$ Praetorius, Syntagma musicum II, 92.

${ }^{27}$ Cf. Theodoricus, Corona templi, K4r; Dieterich, Vlmische Orgel Predigt, 23; Saher, Organolustria, 29; Olearius, Das fröliche Hallelujah, D1r; Sagittarius, Das dem Allmächtigen, 30; Feuerlein, Schuldiges Lob Gottes, 14. A new, rationalistic approach characterizes the last sermon (Richter, Vivum Dei organum, 20), where the use of glass as a constituent material for an organ is questioned on grounds of stability.

${ }^{28}$ Schultetus, Musica ecclesiastica, F2r-G2v.

29 "In den Historien gebühret sich nicht von geringen oder schlechten dingen zu schreiben/ sondern darin werden billich nur solche Sachen erzehlet/ die denckwürdig seyn/ [...]. Daher möchte nun wol ein Aristarchus seinen spott darauß treiben/ das man vom Orgelbaw etwas zum Gedächtnüß auffzeichnen wolle/ weil es nicht so groß zu achten/ das es der Gedächtnüß würdig. Aber wir geben zwar gerne zu/ das solche geringe Sachen auffzuzeichnen nicht eben sich gebür in universali historia oder sonst grossen Historischen Wercken Wie denn ein solches der Marcellinus (quo nemo melius magnitudinem Rom[anorum] descripsit) vor sich gehabt. Aber die etwan einer Stadt Geschichte beschrieben/ haben auch nicht sich verdriessen lassen von geringern Sachen/ als von vornemen Gebäuden/ vnd dergleichen zu schreiben/ ja auch etliche wol absonderlich solcher Gebäwde Beschreibung ans Liecht gegeben. Daher es denn so viel weniger vns zuverdencken/ wenn wir eine kurtze Beschreibung dieses Orgelbaws hiher setzen. Denn dasselbe ja verhoffentlich wo nicht von andern/ doch von den Einwonern dieser Stadt der Gedächtnüß nicht vnwürdig geachtet werden wird.” Ibid., F2r-F2v. 
Schultetus's reflections offer a significant testimony to the new dignity that was accorded in the seventeenth century to the organ and other musical instruments - "slight or poor things" in relation to established historical narratives. With his Organographia, Praetorius became one of the first authors to respond to this change of climate, dedicating an entire monograph to a subject that had formerly not seemed deserving of appreciation. ${ }^{30}$

The history of organs on the one hand, and the specifications of contemporary German organs on the other, were two central topics covered by Praetorius that proved to be of interest to the authors of organ sermons. The earliest sermon influenced by the Syntagma musicum provides a good overview of the complete spectrum of issues for which reference back to Praetorius was made. This is the work of Hieronymus Theodoricus, the minister in Sommerhausen, near Würzburg, which was a Protestant enclave where the work of the musician had already penetrated by 1621 . The example of Theodoricus illustrates the ways in which preachers typically used their literary sources. On three occasions Theodoricus explicitly mentions his Praetorius-related sources in marginalia, giving their page numbers correctly. ${ }^{31}$ In addition, there are three quotations from Praetorius that do not have their origin divulged, the first of which is:

In the time of the famous musician Orlando di Lasso the musical establishment at the Bavarian court consisted of thirty persons: twelve basses, fifteen tenors, thirteen altos, sixteen choirboys, five or six castratos or eunuchs and thirty instrumentalists. What a pleasure must it have been to hear them all together! $!^{32}$

This only slightly altered passage ${ }^{33}$ offered an important point of reference to Theodoricus regarding the size of one of the most famous German court chapels. In the same connection he added information taken from a sermon by the Saxon court chaplain Matthias Hoë von Hoënegg, who had described the various ensembles of musicians that in 1617 had been summoned to Dresden to celebrate the centenary of the Reformation under the direction of Heinrich Schütz. ${ }^{34}$ Obviously, neither example can bear comparison with the music that David is supposed to have introduced to the temple of Jerusalem, but they do help Theodoricus to portray the grandeur of these biblical ensembles in a fitting light. ${ }^{35}$

The second covert quotation from Praetorius deals with the above-mentioned organs of glass and alabaster that could be admired in the cabinets of curiosity of certain noble households of the Early Modern Age:

Leander writes that he saw a very melodious organ in Venice made solely out of glass. A skilful Neapolitan master has built an exceedingly beautiful organ whose chest, pipes,

${ }^{30} \mathrm{Cf}$. Praetorius, Syntagma musicum II, [dedicatory texts], fols $2 \mathrm{r}$ and $7 \mathrm{v}$.

${ }^{31}$ Theodoricus, Corona templi, K2v, M2r.

32 " $Z$ u zeiten Orlandi de Lasso deß weitberühmbten Musici, solle am Fürstlichen Bäyrischen Hof die Musica von dreissig Personen starck bestellt gewesen seyn/ als zwölff Bassisten/ fünffzehen Tenoristen/dreyzehen Altisten/ sechzehen Capellknaben/ fünff oder sechs Capunen oder Eunuchis, vnd dreissig Jnstrumentisten. Solts einer gern zusammen gehört haben.” Ibid., K3r.

${ }^{33}$ Cf. Praetorius, Syntagma musicum II, 17.

${ }^{34}$ See more about this sermon and his context in Scheitler, "Lutherus redivivus", 176-183.

${ }^{35} \mathrm{Cf}$. Theodoricus, Corona templi, K3v. 
keyboard and bellows were of alabaster. It was presented to Friderico, Duke of Mantua. Similar positive organs, in which the entire case, including the pipes and the keyboard, was made entirely out of glass and alabaster, were exhibited several years ago, in an art collection belonging to an elector, as newly invented instruments. ${ }^{36}$

The third quotation is an excerpt from the preface to Girolamo Diruta's treatise $I l$ Transilvano as translated by Praetorius in his Syntagma musicum:

Furthermore, just as beautiful, skilful paintings attract the eye of the beholder, the lovely, sweet harmony penetrates the secret thoughts and feelings of the listeners as it strikes their ears. Enraptured, so to speak, by the sound, they will follow the sermons more attentively, and the lovely sound will persuade and move them to join in the praise sung to the High and Divine Majesty. ${ }^{37}$

The following passage is evidently based on a knowledge of the list of specifications assembled by Praetorius:

Many similar artful, graceful and imposing organs, which one cannot see or hear without astonishment, can be found all over Germany: in Constance, Ulm, Danzig, Rostock, Lübeck, Stralsund, Lüneburg, Breslau, Magdeburg, Brunswick, Leipzig, Dresden, Halberstadt, Bayreuth and other towns. ${ }^{38}$

Taken as a whole, our analysis shows that Theodoricus had read volumes 1 and 2 of the Syntagma musicum carefully, drawing information from it a total of seven times during the course of his text. It is interesting to note that this selection of topics, albeit made at the very beginning of the organ sermon tradition, defines the entire theological reception of the Syntagma musicum that was to follow. The example by Conrad Dieterich (1624), chronologically the second example, exhibits almost the same constellation of cited passages. The mention of the Munich court chapel and the organ inscription from

36 "Leander schreibt/ daß er zu Venedig ein sehr wolklingende Orgel/ aus lauter Glaß gemacht/ gesehen habe. Jn gleichem hat ein kunstreicher Meister von Neapolis/ ein überauß schöne Orgel zugerichtet/ darinnen Laden/ Pfeiffen/Clavier vnnd Blaßbälg/ alles von Alabasterstein gewesen/ so er nachmals Friderico/ einem Hertzogen zu Mantua verehret. Dergleichen Positiv/ da das gantze gehäuß sampt den Pfeiffen vnnd Clavier von eytel Glaß vnnd Alabaster zumal gemacht/ seynd vor wenig Jahren in ein Churfürstliche Kunst=Kammer/ als newerfundene Werck präsentirt worden." Ibid., K3v-K4r.

37 "Dann gleich wie die schöne/ vnd künstlich wolgemachte Bilder vnnd Conterfey der anschawenden Augen an sich ziehen/ also auch durchdringet die liebligkeit der süssen wolklingenden Harmoni/ vnd Concenten die heimliche Gedancken vnnd Affecten/ wann sie in der Zuhörer Ohren fället/ daß dieselbige gleichsam in etwas entzuckt/ den Predigten viel tiefsinniger nachdencken/ auch durch die liebliche resonantz/ dem Lob/ welches der hohen göttlichen Majestat gesungen wird/ bey zu wohnen/ vnd zu zuhören viel mehrers afficirt vnnd bewogen werden.” Ibid., Llr.

38 "Viel solcher künstlicher/ zierlicher/ ansehlicher Orgelwerck werden noch hin vnd wider in Teutschland/ als Costnitz Vlm/ Dantzig/ Rostock/ Lübeck/ Stralsund/ Lüneburg/ Preßlaw/ Magdeburg/ Braunschweig/ Leiptzig/ Dreßden/ Halberstatt/ Beyreuth/vnd anderer orten mehr gefunden/ die man wol ohne verwunderung nicht weder sehen noch hören kan.” Ibid., K4r. 
Perugia are the only topics missing when a comparison is made with Theodoricus. In their place Dieterich includes Praetorius's account of the organ that Solomon was said to have erected in his temple. ${ }^{39}$ There are a total of six references to Praetorius.

After the Thirty Years' War, when many German churches and organs that had been destroyed were rebuilt, the organ sermon enjoyed its heyday. Praetorius is a constant presence in the texts of this period. However, the intensity of the dialogue with him does not increase, but in fact becomes narrowed to specific portions of the selection marked out by Dieterich and Theodoricus. One now usually finds between one and three such passages in an organ sermon. ${ }^{40}$ The topic of Solomon's organ proved to be particularly popular and durable. It is mentioned in nineteen of the examined texts. ${ }^{41}$ The reason for this popularity is easy to explain. There were no other historical reports concerning Solomon's organ, nor was it ever mentioned in the Old Testament. ${ }^{42}$ Praetorius's descriptions therefore provide the sole evidence for this item. However, the theologians, skilled in source criticism, did not lend him their unconditional trust. Dornfeld, who used his sermon in 1733 for an academic treatise on Old Testament music, distanced himself from Praetorius, arguing: "since there is nothing about it either in Scripture or in other accounts, we readily consider it an unfounded Jewish fable". ${ }^{43}$

In 1765 the last of the authors wrote - without citing Praetorius as a source and using only the conditional tense:

If it were certain that Solomon ordained the erection of an organ in the temple at Jerusalem, as the Jewish teachers assert, this would also confirm its antiquity. ${ }^{44}$

The remarkably long-lasting continuity of this transfer of knowledge was based on a professional system of scholarly interpretation and exchange of information that was an

${ }^{39}$ Cf. Praetorius, Syntagma musicum II, 84; Dieterich, Vlmische Orgel Predigt, 10.

${ }^{40}$ There is only one exception: Johannes Melchior Vetterlein drew six topics from the Syntagma musicum II; cf. Vetterlein, Geistlich- und Gott wohlgefälliges Lob- und Danck-Opffer, 19-20, 22 and 25.

${ }^{41}$ The following list of seventeen sermons mentioning Solomon's organ gives only the surname of the author (in chronological order) and the page-number for the reference. Complete bibliographical information can be found in the Bibliography, section Sources, 1. Organ sermons quoting Praetorius: Dieterich, 10; Peisker, 41; Olearius 1664, B3v; Olearius 1667, C4v; Weber, C1v; Hartmann, 9; Grafunder, C2v; Schneider, B1; Vetterlein, 19; Roscher, 4; Sagittarius, 26; Steinfeld, 9; Feuerlein, 11; Dornfeld, 38; Skubowius, 22; Linke, 17; Grosse, 33. Solomon's organ is also referenced in the theological publications of Albrecht, Volumen concionum miscellanearum, 151, and Mithobius, Psalmodia christiana, 290.

${ }^{42}$ For a modern discussion of the early Jewish organ tradition, see Frühauf, The Organ and its Music in German-Jewish Culture, 11-26.

43 " [...] da weder in der Schrifft noch in andern Historien etwas zu finden, halten wir es billig vor eine ungegründete und Jüdische Fabel.” Dornfeld, Die Dem Herrn von neuem geweyhte Heilige Wohnung, 38.

44 "Wäre es auch gewiß, was die jüdischen Lehrer aussagen, daß Salomo eine Orgel in den Tempel zu Jerusalem setzen lassen, die ihres gleichen nicht gehabt habe, so würde ihr Alterthum auch damit bekräftiget." Grosse, Die heiligen Verrichtungen, 33. 
established feature mainly of theology during this period of history. The most important tools for a minister, who had to preach regularly in front of his parishioners, were exemplary sermons for diverse occasions, which were collected systematically for this purpose in the Early Modern Age ${ }^{45}$ In the field of organ sermons the Vlmische Orgel Predigt by Conrad Dieterich and the Rothenburg organ sermon by Johann Ludwig Hartmann became key texts, thanks partly to the authority of the writers and partly to the inclusion of these two occasional prints in bound collections. Both sermons contain quotations from Praetorius that subsequently circulated.

Whereas the exceptional status of the Dieterich sermon is generally known, ${ }^{46}$ in the case of Hartmann we can work out which ministers drew their knowledge of Praetorius from his sermons, because of an error this churchman made: the Rothenburg superintendent referred to Praetorius's treatise incorrectly as Systema musicum, ${ }^{47}$ an error taken over by two other authors. ${ }^{48}$ The case of Conrad Feuerlein's sermon is especially complex. Feuerlein borrowed from the Rothenburg sermon a passage that combines a section of Diruta's treatise with Hartmann's own text. ${ }^{49}$ It is puzzling that he did not recognize the origin of Hartmann's Diruta quotation, for he belongs to the few authors who had access to Praetorius's text and worked with volumes 1 and 2 of the Syntagma musicum..$^{50}$ In other words, fragments of Praetorius entered Feuerlein's sermon both in a direct and in a mediated way. To make things even more complicated, Hartmann himself had borrowed the Diruta quotation, in connection with a long passage about the sound of the trumpet, from Theodoricus. ${ }^{51}$ Consequently, this earlier organ sermon must have been Hartmann's main source. We can accordingly trace a line of transmission passing from Diruta via Praetorius, Theodoricus and Hartmann down to Feuerlein.

Homiletic compendia were of great importance for the "canalization" of the reception of Praetorius, even though their use was so common that ministers often neglected to mention them. To give one example: Caspar Titius published a thematically organized collection of loci communes on various topics relevant to theology. ${ }^{52}$ In the first edition of these Loci theologici historici, dating from 1633, only scant material can be found under the lemma "organ". ${ }^{33}$ In the second edition (1657) Titius added several extracts from Praetorius that replicate the series of topics chosen by Theodoricus and Dieterich (see Appendix 1). Credit should be given to Titius's philological accuracy, which enabled the

${ }^{45}$ Braun, "Orgelpredigtdrucke in Regensburger Bibliotheken", 218-232.

${ }^{46}$ Ibid., 209-217, 238-239; Braun, "Die Orgelpredigt", 24-27; Sato, "Theologische Disputationen”, 104.

${ }^{47}$ Hartmann, Denck- und Danck-Säule, 9.

${ }^{48}$ Schneider, Das Lieblich-klingende Orgeln und Saiten-Spiel, B1r; Steinfeld, Christliche OrgelPredigt, 29.

${ }^{49}$ Feuerlein, Schuldiges Lob Gottes, 18-19.

${ }^{50}$ Ibid., 14-15.

${ }^{51}$ Compare Hartmann, Denck- und Danck-Säule, 19, with Theodoricus, Corona templi, L1r-L1v.

${ }^{52}$ Rehermann, Das Predigtexempel der protestantischen Theologen, 200-205, 230-233 and 257-279.

${ }^{53}$ See Titius, Loci theologiae historici, 392-393. 
authors of sermons to substantiate the origin of the Diruta excerpts without ever having consulted the primary sources.

At the end of the seventeenth century Johann Friedrich Mayer achieved even greater precision in his Museum ministri ecclesiae. He offered his readers a complete reprint of the chapter "Zu welcher zeit ohngefehr/ vnd von weme die Alten Orgeln erfunden worden" (Syntagma musicum II, 89-93) ${ }^{54}$ and absorbed it into an even longer essay on organ history where Dieterichs' Vlmische Orgel Predigt functions as yet another essential reference text. Finally, the Geistliche Vorraths-Kammer zu Predigten/Jn allerhand Fällen und Begebenheiten (1702) by Jacob Reichmann - a collection of model sermons for various casual occasions - should be mentioned. This organ sermon mentions Praetorius's name twice. $^{55}$

The means of knowledge transfer that I have discussed here contributed significantly to the emergence of a few selected topoi from the Syntagma musicum that were able to lead a life of their own, isolated from their original context and often completely detached from their author. Indeed, only in the 1620s did theologians like Dieterich and Theodoricus deal directly with the work of Praetorius. From 1650 onwards his treatise served, rather, as proof of superficially presented professional knowledge. Rare exceptions occur in Gerlach and Feuerlein. A hundred years later, under the influence of the Enlightenment, the questions initiated by Praetorius were reopened for a fundamentally new academic discourse.

The significance of the Syntagma musicum, then, seems to reside in its unexpected resonance. The impact of Girolamo Diruta's preface to the Transilvano as translated by Praetorius is especially noteworthy. One particular element, introduced by Diruta in the form of a quotation, proved to be especially popular: the organ inscription "Haec si contingunt terris, quae gaudia coelo" from Perugia. ${ }^{56}$ This is part of an emblematic complex consisting of a typical "inscription" (the poetic line) and a "subscription" (the explanation of the hidden meaning that has to be deciphered). A "picture", in the normal sense, is missing. Its place is taken by the organ and the music it produces. Nineteen German theologians cited the "Verßlein: Haec si contingunt terris, quae gaudia Coelo?"57 (see Appendix 2). The list of these quotations shows that Diruta's model stimulated the imagination of the authors. Through the application of techniques of baroque amplification the annotated translation stemming from Diruta was further embellished, changed or supplemented by the Latin version appearing in Syntagma musicum I. There were also several attempts at a poetical translation into German, which in some cases expand the model into a quatrain or combine it with passages from the carol In dulci jubilo. Some authors, in contrast, preferred to reduce the emblem to the Latin inscription. In this manner a vision of heavenly music, which was so central to baroque music theology, ${ }^{58}$

${ }^{54}$ Mayer, Museum ministri ecclesiae, vol. 2, 25-31.

${ }^{55}$ Reichmann, "Organi laudes", 197-198.

${ }^{56}$ Diruta, Il Transilvano, s.p.; Praetorius, Syntagma musicum II, 88.

${ }^{57}$ Ibid.

${ }^{58}$ See, for example, the praise of heavenly music in an elevated, jubilant style intertwined with poetic lines in Frick, Musica christiana, 93-99. 
was condensed into a succinct "device" that proved a perfect tool for the communication strategies of a sermon. The device became so popular ${ }^{59}$ that after 1700 it was used as an inscription on organs in Groden (near Cuxhaven) ${ }^{60}$ and Stettin. ${ }^{61}$

That apart, several further ideas formulated by Diruta seem to have fascinated the theologians. As the selection of quotations presented by Titius shows, the comparison of visual and auditory media attracted special interest. It represented a comprehensive attempt to conceptualize the new category of affect. ${ }^{62}$ Another topic derived from Diruta, the comparison of the organ with the human body, would deserve separate examination in its own right. ${ }^{63}$ One may assume that the Diruta passage transmitted by Praetorius stimulated general interest in the allegorical description of the organ and its stops. In the period between 1650 and 1750 such allegories were indeed a favourite ingredient of baroque organ sermons. Finally, it is not improbable that the term "Rex omnium Instrumentorum", ${ }^{64}$ which survives today in the expression "king of the instruments" (German: "Königin der Instrumente"), goes back to Diruta-Praetorius, becoming embedded in cultural memory through a multitude of texts, among them organ sermons.

Even though his musical knowledge exceeded by far the requirements of the ministers, Praetorius assumed the role of an intermediary in an intercultural and interconfessional exchange. His impact was seminal, and not only because copies of Diruta's Transilvano were hardly available in Germany. ${ }^{65}$ Whereas Catholic Italy lay within the traditional purview of German musicians, it was not a part of the personal topography of a Lutheran theologian. Only thanks to the Syntagma musicum did major issues of musical thought originating from Italy pass over to Germany, where they became included in the theological discourse of the day. Therefore, in a way different from the one he had expected, Praetorius attained the goal he had set himself in the epistola dedicatoria of Syntagma musicum I: to assist the establishment of concio and cantio (sermon and song) as the twin pillars of Lutheran faith. ${ }^{66}$

${ }^{59}$ Johann Mattheson was also acquainted with this motto; cf. his Veritophili deutliche BeweisGründe, 41, and Behauptung der himmlischen Musik, 64.

${ }^{60}$ Tesdorpf, "Inschriften von Grabdenkmälern”, 56.

${ }^{61}$ Zickermann, Historische Nachrichten, 79.

${ }^{62}$ Two scholars have emphasized the importance of this particular quotation for Lutheran aesthetical thought: see Havsteen, "Das 'Music-Büchlein"”, 67, and Steiger, Der Orgelprospekt im Kloster Lüne, 67. Steiger was not aware of the Italian origin of the passage, nor of the role that it played for Praetorius.

${ }^{63}$ This topic has been the subject of a paper by Raymond Dittrich delivered at the conference "Orgelpredigten in Europa (1600-1800). Musiktheoretische, theologische und historische Perspektiven” (Regensburg, 16-18 May 2019).

${ }^{64}$ Praetorius, Syntagma musicum I, 141.

${ }^{65}$ See Lesure, Écrits imprimés concernant la musique, RISM, B/VI/1, 268.

${ }^{66}$ Praetorius, Syntagma musicum I, b1r; Arnold, "“Concio \& Cantio"”. 


\section{Appendix 1}

\section{Caspar Titius, "3. Orgeln", in Loci theologici historici, oder theologisches Exempel- Buch (Wittenberg: Fincelius, 1657), 819-821.}

1. Wie die schönen vnd künstlichen wolgemalten Bilder der anschawenden Augen an sich ziehen: eben also durchdringet auch die Liebligkeit der süssen wolklingenden Harmonia und Concenten die heimliche Gedancken und affecten, wenn sie in der Zuhörer Ohren fellet. Derhalben hat die Orgel billich ihren Sitz in den Kirchen und Tempel/ damit durch ihre anleitung Gottselige und andächtige Hertzen auffgemuntert/ und durch ihren lieblichen resonantz, dem lobe/ welches der Hohen und Göttlichen Majestät gesungen wird/ zuzuhören/ bey zu wohnen und auff zu warten/ angereitzet und gleichsam genötiget werden.

Und bleibt wol war/ das unter allen/ was Instrumenta können und mögen genennet werden/ die Orgel die fürnembste und Oberste stelle praeminentz und Würde habe/ alldieweil sie alle süssigkeit und liebligkeit/ so die andern Instrumenta in sich haben/ oder zu wege bringen können/ ihr alleine zumisset und zuschreibet: Bevoraus/ weil sie solchen Grad der Hoheit erreichet/ das keine Musica oder Seitenspiel auff dem gantzen Erdboden ist/ dadurch [p. 820] der lieben heiligen Engel liebliche Harmonia und gesang zu Gottes lobe/ eigentlicher repraesentiret und abgebildet werde/ als durch sie. Welches in dem Organo ad D. Petrum in Perusio gar fein ausgetruckt vnd gegeben ist mit diesen verßlein: Haec si contingunt terris, quae gaudia coelo? Weil dieses auff der Welt geschicht was wird allererst vor frewde vnd lieblich gedöhne im Himmel sein? Als wolte er sagen: Weil man auff dieser Erden so eine schöne/ liebliche wolklingende Musica haben und zuwege bringen kan; mein Gott/ was für unaussprechliche Frewde/ Wonne und Liebligkeit/ mus allererst sein des Engelischen Chors und der Gottseligen Seelen im Himmel. Michael Praetorius 2. p. Syntag: Mus ex Hieronymi Dirutae Itali praefat.

2. Anno 757. hat Käyser Constantinus von Constantinopel geschickt/ unter vielen andern geschencken Pipino dem Franckdeutschen Könige ein kunstreich Positiv oder Orgelwerck/ so das erste war/ so in Occident gesehen oder gehöret worden/ darüber sich jederman verwunderte. Hie von nahmen etliche Kunstreiche Meister zu Nürnberg anweisung/ Positiv und Orgeln zu machen/ die nun mehr/ Gott sey lob/ so gemein worden sint/ das fast kein fürnehmes Dorff ist/ da man nicht findet solche wolklingende Wercke/ der Städe zu geschweigen/ do grosse unkosten drauff gewendet wird. Alphab. Hist. ex Crusio p. 1. Annal.

3. Dje Orgel im Münster zu Ulm ist auffgerichtet Anno 1576. mit 14. Register/ und 1700. Pfeiffen: Renoviret aber und vernewret Anno 96. hat beneben drey Claviren und pedal itzo 45. Register und 3000. Pfeiffen/ deren die gröste 315. Ulmische Maß halten: ist jede 24. schuchlang/ und hat 23. Zol dem Centro nach. D. Conrad Tietrich in der 1. Ulmischen Einweihungspr.

4. Das Werck zu Rostock/ welches von Heinrich Glovatz Bürgern daselbst gebawet/ und Anno 93. absolviret worden/ auch zu bawen 5000. fl. gekostet/ hat 39. Stimmen/ 14. Blasbelge/ und 3. Clavir: deren das oberste zum Oberwerck/ das mittelste zur Brust: [p. 821] und das unterste zum rück positiv gehöret/ und gebraucht wird. Mih. Praetorius 2. p. Syntag. Musicis. 
5. Jn der Schloskirchen zu Grüningen war Anno 596. ein Orgelwerck von Meister David Becken Bürgern und Orgelmachern in Halberstadt auff gerichtet/ welches 59. Stimmen/ Tremulant und Coppel zu beyden manualn vermag. Ibidem.

6. Die Orgel im Thumb zu Magdeburg von M. Heinrich Compenio auffgerichtet vermag 42. Stimmen: 2. Tremulantien Vogel gesang: Trummel/ und zwey Clavis von C bis $\mathrm{c} /$ pedal von $\mathrm{g}$ bis ins $\mathrm{d}$ : hat 12. lederne Blasbelge. Ibidem.

7. Das Werck zu Hall bey unser lieben Frawenkirchen hat 31. Stimmen: das bey S. Niclaus zu Leiptzig 29. Stimmen: und das zu S. Thomas daselbst 25. Stimmen. Ibidem.

8. Der Herr Doctor Titrich in seiner Orgelpredigt lehret/ wie wir Christen uns selbst zu lebendigen vernünfftigen und verstendigen Orgeln machen sollen/ unser Leib sol das Corpus solcher Orgel sein: Unser Mund sol an derselbigen die Pfeiffen: Unser Zung sol in den pfeiffen das Zünglein: Der Odem oder wint so darein geblasen/ sol unser gemüth sein. Das Clavier und Pedal solcher unser geistlichen Orgel sol das Hertze sein. Die Register deren sollen unsers Hertzens und Gemüths affecten vnd begirten sein. Der Organist sol der H. Geist sein/ welcher da ist mit gaben siebenfalt: der Finger in Gottes rechter Hand/ der sol mit seinem [sic] Fingern das Clavir unsers Hertzens schlagen/ sie durch den wint seines Wortes/ bewegen/ damit unser Leib unser Füsse/ unsere Hände/ Sinn und Gedancken unsere affecten und begirden/ einen rechten und geistlichen lieblichen anmuhtigen resonantz geben/ dadurch cum chordis corda, cum fidibus fides mit den Seiten Clavir und klange die Hertzen/ mit den Glauben die werck und that zusammen stimmen. M. Georg. Albrecht Prediger zu Augspurg in der handwerckszunft.

\section{Appendix 2}

Quotations of the organ inscription "Haec si contingunt Terris, quae gaudia Coelo" 1593 Diruta, "L'Avttore dell'opera al prvdente lettore", in Il Transilvano

[...] quelche nell'Organo di San Pietro di Perugia si mostra con vn bel verso dicendo. Haec si contingunt Terris, quae gaudia Coelo? Come se dicesse, Se in Terra si gode di tale soaue armonia, con tanto artifitio procurata all'orecchie humane; qual godimento, \& gioia debbe essere de' chori Angelici \& de Beati spiriti in Cielo?

1615 Praetorius, Syntagma musicum I, 143

Idipsum in Organo ad D. Petrum in Perusio expressum hoc versiculo: Haec si contingunt terris, quae gaudia coelo? quasi dicat: si in hisce terris ea est concentus \& harmoniae dulcedo, quantum gaudium \& laetitiae erit Angelici chori \& beatorum spirituum supernè in coelestibus?

\section{Praetorius, Syntagma musicum II, 88}

Welches in dem Organo ad D. Petrum in Perusio gar fein außgetruckt vnd gegeben ist mit diesen Verßlein: Haec si contingunt terris, quae gaudia Coelo? Weil dieses auff der Welt geschicht/ was wird allererst vor Frewde vnd lieblich Gedöhne im Himmel seyn? als wolte er sagen: Weil man vff dieser Erden so eine schöne/ liebliche wolklingende Musica haben/ vnd zuwege bringen kan; mein Gott/ was vor vnaußsprechliche 
Frewde/ Wonne vnd liebligkeit/ mus allererst seyn deß Englischen Chors vnd der Gottseligen Seelen im Himmel?

\section{Theodoricus, Corona templi, M2r}

Daher zu Berus/ einer Statt im Welschland/ an der Orgel zu Sankt Peter geschrieben stehet: Haec si contingunt terris, quae gaudia, coelo? das ist: Weil man auff dieser Erden so eine schöne liebliche/ wolklingende Music zuwegen bringen/vnd haben kan/ ewiger Gott/ was für eine vnaußsprechliche Frewd/ Wonne vnnd Lieblichkeit muß allererst seyn deß Englischen Chors/ vnnd der gottseligen Seelen in dem Himmel?

1624 Dieterich, Vlmische Orgel Predigt, 41

$\mathrm{Zu}$ Peru in Italia, steht an der Orgel in S. Peters Kirch dieser Vers mit Lateinischen Worten angeschrieben/

Haec si contingunt terris, quae gaudia coelo?

Heist zu vnserm Teutschen so viel:

Wann solche Frewde ist auff Erden/

Was wird für Frewd im Himmel werden?

1652 Peisker, Stolpenische Ehren-Crone, 54

Haec si contingunt terris qvae gaudia caelis? Sol auf der Orgel in S. Peters Kirchen zu Perusia/ einer namhafften Stadt in Welschland stehen/ das ist:

So solche grosse Freud auf Erden ist zuhaben:

Was wird doch wohl für Freud' im Himmelssaal uns laben?

1657 Titius, Loci theologici historici, 820

Welches in dem Organo ad D. Petrum in Perusio gar fein ausgetruckt vnd gegeben ist mit diesen verßlein: Haec si contingunt terris, quae gaudia coelo? Weil dieses auff der Welt geschicht was wird allererst vor frewde vnd lieblich gedöhne im Himmel sein? Als wolte er sagen: Weil man auff dieser Erden so eine schöne/ liebliche wolklingende Musica haben und zuwege bringen kan; mein Gott/ was für unaussprechliche Frewde/ Wonne und Liebligkeit/ mus allererst sein des Engelischen Chors und der Gottseligen Seelen im Himmel. Michael Praetorius 2. p. Syntag: Mus ex Hieronymi Dirutae Itali praefat.

\section{Olearius, Encoenia HierOrganica, B4r}

[...] daher an der Orgel zu Perusia in Welschland diese Worte zu finden: Haec si contingunt terris, qvae gaudia coelo? So dieses auf der Welt uns wiederfähret, was wird für Freud und Liebligkeit im Himmel seyn/ da die Engel singen und musiciren nova cantica, und die Schellen klingen in Regis curia, Eya weren wir da!

1671 Weber, Das Gott=Lob=Schallende Hosianna, F1v

Ein verständiger lässet ihn den Orgellklang ferner sein (2.) Consolationem, Eine Hertzens=Erqvickung/ und gedencket bey sich/ Haec si contingunt terris, qvae gaudia caelo? wie solche Wort zu Perusia in Welschland an einer Orgell sollen gefunden werden/ das ist: So hier auf Erden eine so tröstliche und hertzerqvickende Musica zuhören/ was vor Liebligkeit wird denn in Himmel gehöret werden?

\section{Hartmann, Denck- und Danck-Säule, 26}

Daher in einer Stadt im Welschland an der Orgel zu S. Peter geschrieben stehet: Haec si contingunt terris, quae gaudia, coelo. Das ist/weil man auf dieser Erden so eine schöne liebliche und wolklingende Music zu wege bringen und haben kan/ ewiger 
Gott/ was für ein unaussprechliche Freud/ Wonne und Lieblichkeit muß allererst seyn deß Englischen Chors/ und der Gottseligen Seelen in dem Himmel/ [...].

1673 Schnitzler, Orgel Predigt, fol. 14v

Welches in dem Organo ad D. Petrum in Perusio gar fein auszgedruckt und gegeben ist mit diesem Verslein: Haec si contingunt terris quae gaudia coelo? das ist/ weil dieses in diser Welt geschicht/ was wird allererst vor freude und lieblicher Klang im Himmel seyn? Als wolts sagen: weil mann auff dieser Erden so eine schoene liebliche wohlklingende Musica haben und zu wege bringe kan/ mein Gott was fuer unauszsprechliche Freude/ Wonne und Liebligkeit musz allererst seyn des Engelischen Chors und der gottseligen Seelen im Himmel.

1675 Grafunder, Das fröliche Halleluja, C4r

So offt Jhr ins künfftige die Orgel werdet hören spielen/ so lasset Euch auch den Orgel=Klang seyn/ eine Hertzerqvickung und Erinnerung der Himmlischen und Engelischen Music, und gedencke ein jeder bey sich: Haec si contingunt terris, qvae gaudia coelo? So hier auff Erden eine solche tröstliche und erqvickende Musica zuhören ist/ was vor Liebligkeit wird denn im Himmel gehöret werden?

1676 Schneider, Das Lieblich-klingende Orgeln und Saiten-Spiel, E4r

So offt ihr demnach/ ihr Lieben/ künfftig dieses schöne Orgelwerck werdet klingen hören/ so erinnert euch dieses darbey/ und dencket/ wie auf einer Orgel zu Basel geschrieben stehet: Haec si contingunt terris, qvae gaudia coelo! Kan einen das lieblichklingende Saitenspiel in dieser Welt so frölich machen/ dessen man doch/ nach dem Exempel Salomonis, (Pred. 2, 9. 11.) bald überdrüßig wird/ wie wirds doch einmal so lieblich u[nd] lustig zugehen im ewigen Leben. Ey derowegen so will ich mich befleißigen/ daß ich auch möge dahin kommen/ da die Engel singen Nova cantica, und die Schellen klingen in Regis Curiâ, Eja weren wir da!

1681 Bucher, Gott und Gnug, 16-17

Bevoraus weil sie solchen Grad der Hoheit erreichet/ daß keine Musica oder Saitenspiel auff dem gantzen Erdboden ist/ dadurch der lieben Heil[igen] Engel liebliche Harmonie und Gesang zu Gottes Lobe eigentlicher repraesentiret und abgebildet werde als durch sie/ Welches in dem Organo ad D. Petrum in Perusio gar fein ausgedruckt und gegeben ist mit diesem Verßlein: Haec si contingunt terris, qvae gaudia coelo? Weil dieses auff der Welt geschicht/ was wird allererst vor Freude und lieblich Gethöne im Himmel seyn? als wolte er sagen: Weil man auff Erden so ein schöne liebliche wohlklingende Music haben und zuwege bringen kan/ mein Gott/ was vor unaussprechliche Freude/ Wonne und Liebligkeit muß allererst seyn des Englischen Chors und der Gottseligen Seelen im Himmel?

1680 Vetterlein, Geistlich- und Gott wohlgefälliges Lob-und Danck-Opffer, 25

Dannenhero in einer Stadt in Welschland an der Orgel zu S. Peter geschrieben stehet: Haecsi contingunt terris, quae gaudia coelo? h[ic] e[st] Weil man auf dieser Erden so eine schöne liebliche und wohlklingende Music zuwegen bringen und haben kan/ ewiger Gott/ was für eine unaussprechliche Freuden=Music wird im ewigen Leben seyn/ allwo alles wird uffs vollkommenste erscheinen? 


\section{Sagittarius, Das dem Allmächtigen abzustattende Lob, 43}

Hierauff haben die Einwohner der Stadt Perusinae in Etrurien gesehen/ wenn sie an die in der Peters=Kirche stehende Orgel diesen Hexametrum geschrieben:

Haec si contingunt terris, qvae gaudia coelo?

Wenn solche Freude ist auff Erden/

Was wird vor Freud im Himmel werden?

Diesen Vers hat Hieronymus Diruta fein ausgeleget: Si in hisce terris ea est concentus $\&$ harmoniae dulcedo, qvantum gaudium \& laetitiae erit Angelici chori \& beatorum Spirituum superne in coelestibus? i[d] e[st] So auff dieser Erden eine solche Liebligkeit der einstimmigen Harmonie/ was vor Freude und Wonne wird in dem Himmel bey dem Englischen Chor und Auserwehlten seyn?

\section{Fetter, Organo-praxis mystica, 44}

Haec si contingunt terris; quae gaudia coelo? Si tanta nobis in carcere, quanta in patria?

Gibt dir ein solches hie Gott in dem armen Leben.

Was wird er dir denn dort in jenem Leben geben?

Jst dieser Kercker hier/ so voller Freud und Lust/

Was wird der Seelen denn dort ewig seyn bewust?

\section{Steinfeld, Eine Christliche Orgel-Predigt, 32}

Haec si contingunt terris, quæ gaudia coelo, sol an einer Orgel in Welschland angeschrieben stehen. Begegnet uns ein so grosse Freud in der Welt/ ô hilff Gott! was vor eine Freude wird seyn in dem Himmel? da wird kein irrdisch Mutät. Kein Concert/ sondern die selbst=ständige Freude unser Hertzen erfüllen

Da wird Gott all's in allem seyn/

Da wird denn recht erklingen

Der G'sang der Heil'gen Engelein

Die Gott zu Ehren singen

Da wird Gott in der Seeligkeit

Gepreiset werden allezeit/

Da wird die Freud angehen/

Die kein Aug hat gesehen.

\section{Reichmann, Organi laudes, 198}

Jn einer Stadt in Welschland ist an der Orgel zu S. Petri geschrieben: Haec si contingunt terris, qvae gaudia coelo? Weil man auff dieser Erden so eine liebliche/ schöne und wohlklingende Music zu wege bringen und haben kan/O ewiger Gott/ was für eine unaußsprechliche Freude/ Wonne und Liebligkeit muß zu finden seyn in dem Engelischen Chor und der Gottseligen Seelen in dem Himmel?

1740 Richter, Die sich über das Gute Freuende Heiligen, 14

Denn sic haec contingunt terris, qvae gaudia coelo? mag ich wohl hiher ziehen, was zu Perusia in Jtalien an einer Orgel in der Kirche zu St. Petri angeschrieben stehen soll, das ist: Macht eine Orgel in der Welt so grosse Freude, was wird nicht im Himmel geschehen, da alle Auserwehlten zu selbstständigen Orgeln und wohlklingenden Pfeiffen werden werden? 


\section{Skubowius, Die heilige Sabbaths-Lust an dem Herrn, 40-41}

Als ein gottseliger Christ eine wohlklingende Orgel hörete, wurde er dadurch so gerühret, daß er gleichsam entzückt sagete:

Haec si contingunt terris quae gaudia coelis! [original footnote: Man will, daß diese Worte auf der Orgel in S. Peters=Kirchen zu Perusia, einer wohnhaften Stadt in Welschland, stehen sollen.]

Klingts so schön auf dieser Erden/

Ey, wie wirds im Himmel werden.

\section{Linke, Der rechte Gebrauch der Orgeln, 22}

Da es, wiewol mit Entfernung aller groben und fleischlichen Begriffe, aus verschiedenen Gründen glaublich ist, daß in jener Welt, nach der Wiedervereinigung unsrer Seele mit dem Leibe, auch gewisse leibliche Ergötzlichkeiten statt finden werden; so ists gar nicht unwahrscheinlich, daß wir da die entzückendsten Lobgesänge hören werden. Wenn der Schall der Musik, wenn die künstlich gespielten Pfeiffen der Orgel uns hier schon vergnügen, da doch immer so viele rauhe und herbe Klagthöne sich in unsre Danklieder einmischen: O wie frölich werden wir da unsern Gott loben, wo Schmerz und Seufzen weichen und er selbst mit mitleidiger Hand alle Thränen von unsern Augen abwischen wird!

\section{Bibliography}

\section{SOURCES}

1. Organ sermons quoting Praetorius

Bucher, Christoph Friedrich. Gott und Gnug, Oder Göttliche Gutthätigkeit. Meißen: Günther, 1681.

Dieterich, Conrad. Vlmische Orgel Predigt. Ulm: Meder, 1624.

Dornfeld, Christian Friedrich. Die Dem Herrn von neuem geweyhte Heilige Wohnung und Hütte des Stiffts. Esslingen: Mäntler, 1733.

Fetter, Michael. Organo-praxis mystica. Görlitz: Hübner, 1689.

Feuerlein, Conrad. Schuldiges Lob Gottes aus den Worten des CL. Psalms. Nürnberg: Endter, 1696.

Gerlach, Georg. ОРГАНОАОГІ ММО, Das ist: Christliche und einfältige doch in Gottes Wort gegründete Orgel-Predigt. Dresden: Bergen, 1651.

Grafunder, David. Das fröliche Hertzerfreuliche und Gott-Lob-schallende Halleluja. Wittenberg: Henckel, 1675.

Grosse, Bernhard Sebastian. Die heiligen Verrichtungen in dem Hause des Herrn. Eisenach: Grießbach, 1765.

Hartmann, Johann Ludwig. Denck- und Danck-Säule Von der Orgel und JnstrumentalMusic Ursprung und Fortpflantzung. Rothenburg: Beer, 1673.

Keltz, Heinrich. Die Billige Orgel-Freude einer Evangelischen Gemeine bey einem neuen Orgel-Werck. Danzig: Schreiber, 1739.

Linke, Friedrich Wilhelm Traugott. Der rechte Gebrauch der Orgeln. Altenburg: Richter, 1766. 
Münstermann, Johannes. "Christliche Orgel Predigt”. In Psalmodia christiana, edited by Hector Mithobius, 378-394. Jena: Berger, 1665.

Olearius, Gottfried. Encoenia HierOrganica, Oder Christliche Orgelweyhe. Halle: Salfeld, 1664.

Olearius, Johannes. Das fröliche Hallelujah Auß dem CL. Psalm. Halle: Salfeld, 1667.

Peisker, Gottfried Siegmund. Stolpenische Ehren-Crone. Dresden: Seyffert, 1652.

Reichmann, Jacob. "Organi laudes”. In Geistliche Vorraths-Kammer zu Predigten Jn allerhand Fällen und Begebenheiten, 191-199. Eisenberg: Meise, 1702.

Richter, Georg. Die sich über das zwiefältige von der Friedrichswäldischen Kirche aus der Hand des Herrn empfangene Gute Freuende Heiligen. Pirna: Grütze, 1740.

Richter, Georg Gottfried. Vivum Dei organum. Schneeberg: Kanngiesser, [1719].

Roscher, Samuel. Organum mysticum Oder Des Herrn Jesu Geistliche Christen-Orgel. Dresden: Riedel, 1686.

Sagittarius, Paulus Martinus. Das dem Allmächtigen abzustattende Einstimmige und einhellige Lob. Altenburg: Richter, [1687].

Saher, Johann Conrad. Organolustria evangelico-Stambachiana. Hof: Mintzel, 1660.

Schelwig, Samuel. Christliche Orgel-Predigt. Danzig: Stolle, 1704.

Schneider, Theodor. Das Lieblich-klingende Orgeln und Saiten-Spiel. Coburg: Mönch, 1676.

Schnitzler, Jacob. Orgel Predigt. Hermannstadt: Jüngling, 1673.

Skubowius, Raphael Jonathan. Daß durch ein wohleingerichtetes Orgelwerck die heilige Sabbaths-Lust an dem Herrn bey einer Christlichen Gemeine könne erwecket werden. Danzig: Knochen, 1749.

Steinfeld, Gottfried. Eine Christliche Orgel-Predigt. Danzig: Stolle, 1695.

Theodoricus, Hieronymus. Corona templi, Das ist: Zwo Predigten von der schönen Kirchen Cron, oder Heiligen Kirchengeschmuck. Nürnberg: Sartorius, 1621.

Vetterlein, Johannes Melchior. Geistlich- und Gott wohlgefälliges Lob-und Danck-Opffer. Bayreuth: Gebhard, 1680.

Weber, Immanuel. Das Gott=Lob=Schallende Hosianna. Leipzig: Spörel, 1671.

2. Other historical sources before 1800

Albrecht, Georg. Volumen concionum miscellanearum. Ulm: Kühn, 1653.

Anwander, Georg. Christliche Predigt: Von der Vocal vnd Instrumentalischen Music. Tübingen: Gruppenbach, 1606.

Diruta, Girolamo. Il Transilvano. Venice: Vincenti, 1593. Facsimile edition, edited by Luisa Cervelli. Bibliotheca musica Bononiensis 2,132. Bologna: Forni, 1969.

Frick, Christoph. Musica christiana. Leipzig: Kober, 1615.

Lang, Johannes, Christliche Predigt: Von dem rechten Christlichen Gebrauch der Music. Tübingen: Gruppenbach, 1602.

Mattheson, Johann. Behauptung der himmlischen Musik: aus den Gründung der Vernunft. Hamburg: Herold, 1747.

- Veritophili deutliche Beweis-Gründe. Hamburg: Schiller, 1717.

Mayer, Johann Friedrich. Museum ministri ecclesiae. Leipzig: Gleditsch, 1690.

Mithobius, Hector. Psalmodia christiana. Jena: Berger, 1665. 
Polantus, Nicolaus. Musica instrumentalis, Von Christlichem Brauch der Orgelwerck vnnd Seytenspiel. Leipzig: Popporeich, 1605.

Praetorius, Michael. Syntagma musicum I: Musicae artis analecta. Wittenberg: J. Richter, $1614 / 15$.

—. Syntagma musicum II: De organographia. Wolfenbüttel: Elias Holwein, 1619.

—. Syntagma musicum III: Termini musici. Wolfenbüttel: Elias Holwein, 1619.

Schultetus, Christoph. Musica ecclesiastica. Stettin: Götzke, 1628.

Titius, Caspar. Loci theologiae historici, oder theologisches Exempel Buch. Wittenberg: Helwig, Müller, 1633.

- Loci theologici historici, oder theologisches Exempel Buch. Wittenberg: Fincelius, 1657.

Zickermann, Christian. Historische Nachricht von den alten Einwohnern in Pommern. Stettin: Conradi, 1724.

\section{LITERATURE}

Arnold, Jochen. “'Concio \& Cantio' - zur Theologie der Kirchenmusik in Michael Praetorius's Syntagma musicum”. In Singen, Beten, Musizieren. Theologische Grundlagen der Kirchenmusik in Nord- und Mitteldeutschland zwischen Reformation und Pietismus (1530-1750), edited by Jochen Arnold, Konrad Küster and Hans Otte, 35-52. Studien zur Kirchengeschichte Niedersachsens 47. Göttingen: V \& R Unipress, 2014.

Braun, Lucinde. "Die Orgelpredigt: Überlegungen zu einer Gattung zwischen Musik und Theologie”. Archiv für Musikwissenschaft 71, no. 4 (2014): 247-281.

—. "Orgelpredigtdrucke in Regensburger Bibliotheken: Versuch einer mediengeschichtlichen Analyse”. In Musikalische Schätze in Regensburger Bibliotheken, edited by Katelijne Schiltz, 189-249. Regensburger Studien zur Musikgeschichte 13. Regensburg: ConBrio, 2019.

Davies, Sarah. "Kirchen Cron or Baalsfeldzeichen? The Organ as a Sign of Confessional Identity, 1560-1660". In Music and Theology in the European Reformations, edited by David J. Burn, Grantley McDonald, Joseph Verheyden and Peter De Mey, 307-340. Turnhout: Brepols, 2019. https://doi.org/10.1484/M.EM-EB.5.116370.

Frühauf, Tina. The Organ and its Music in German-Jewish Culture. Oxford: Oxford University Press, 2009.

Havsteen, Sven Rune. 'Das ‘Music-Büchlein' (1631) von Christopher Frick”. In Singen, Beten, Musizieren. Theologische Grundlagen der Kirchenmusik in Nord-und Mitteldeutschland zwischen Reformation und Pietismus (1530-1750), edited by Jochen Arnold, Konrad Küster and Hans Otte, 53-74. Studien zur Kirchengeschichte Niedersachsens 47. Göttingen: V \& R Unipress, 2014.

Kelber, Moritz. "Leviathan: Die Orgel als Herrschaftsinstrument”. Musiktheorie: Zeitschrift für Musikwissenschaft 34, no. 1 (2019): 83-94.

Lesure, François, ed. Écrits imprimés concernant la musique. Vol. 1, A-L. RISM, B/VI/1. Kassel: Bärenreiter, 1971.

Rehermann, Ernst Heinrich. Das Predigtexempel der protestantischen Theologen des 16. und 17. Jahrhunderts. Göttingen: Schwartz, 1977.

Rigney, James. "Sermon into Print”. In The Oxford Handbook of the Early Modern Sermon, 
edited by Peter McCullough, 198-212. Oxford: Oxford University Press, 2011. https:// doi.org/10.1093/oxfordhb/9780199237531.013.0011.

Sato, Nozomi. “Theologische Disputationen über Kirchenmusik und die darauf bezogenen Reaktionen der Musiktheorie im protestantischen Deutschland zwischen 1650 und 1750". In Singen, Beten, Musizieren. Theologische Grundlagen der Kirchenmusik in Nord- und Mitteldeutschland zwischen Reformation und Pietismus (1530-1750), edited by Jochen Arnold, Konrad Küster and Hans Otte, 93-107. Studien zur Kirchengeschichte Niedersachsens 47. Göttingen: V \& R Unipress, 2014.

Schabram, Kai. "Ursprung und Entwicklung der Musica sacra in der lutherischen Musikgeschichtsschreibung des 16. und 17. Jahrhunderts". Kirchenmusikalisches Jahrbuch 100 (2016): 25-46.

Scheitler, Irmgard. "Lutherus redivivus: Das Reformationsjubiläum 1617; Mit einem Ausblick auf das Jubiläum 1717”. Jahrbuch für Liturgik und Hymnologie 55 (2016): 174-215. https://doi.org/10.13109/9783666572265.174.

Steiger, Johann Anselm. Der Orgelprospekt im Kloster Lüne als Zeugnis barock-lutherischer Bild- und Musiktheologie: Zur Intermedialität von Wort, Bild und Musik im 17. Jahrhundert. Regensburg: Schnell \& Steiner, 2015.

Tesdorpf, Oscar L. "Inschriften von Grabdenkmälern, Gemälden u. s. w. in der Kirche zu Groden”. Mitteilungen des Vereins für Hamburgische Geschichte 13 (1890): 49-57. Walther, Johann Gottfried. Musicalisches Lexicon Oder Musicalische Bibliothec. Leipzig: Deer, 1732.

Warnke, Götz. Die Theologen und die Technik. Geistliche als Techniker, Innovatoren und Multiplikatoren im deutschsprachigen Raum 1648-1848. Hamburg: von Bockel, 1997 


\title{
SYNTAGMA MUSICUM V LUTERANSKIH ORGELSKIH PRIDIGAH SEDEMNAJSTEGA IN OSEMNAJSTEGA STOLETJA
}

\author{
Povzetek
}

Druga knjiga Syntagme musicum, izdana leta 1619, je široko zasnovan glasbeni kompendij, namenjen takratnim glasbenikom. A kako se je to vedenje širilo med uporabniki, doslej še ni bilo deležno sistematične raziskave. Razprava se osredotoča na luteranske orgelske pridige, zbirko besedil, ki so trenutno pod drobnogledom v okviru DFG projekta na Muzikološkem inštitutu Univerze v Regensburgu.

Orgelske pridige predstavljajo skupino virov, ki se stalno sklicujejo na Praetoriusov spis o glasbilih, De organographia. Že leta 1621 je Hieronymus Theodoricus iz traktata prvič črpal snov za svojo pridigo ob posvetitvi orgel v letnem dvorcu pri Würzburgu. Leta 1624 se je na Syntagmo musicum skliceval superintendant in profesor teologije Conrad Dieterich v svoji Ulmski orgelski pridigi. Ta je postala najbolj razširjena orgelska pridiga, ki opredeljuje generični in lokalni okvir tovrstnih besedil. Po tridesetletni vojni je bil Praetoriusov traktat del običajnega znanstvenega aparata tovrstnih pridig. Vsaj petindvajset avtorjev med letoma 1651 (Georg Gerlach) in 1749 (Raphael Jonathan Skubowius) navaja izbrane Praetoriusove navedke. Vendar niso vsi črpali iz izvirne izdaje, saj so mnogi Praetoriusa poznali zgolj iz obstoječih orgelskih pridig, ki pa niso vedno natančno navajale avtorstva navedkov. Ta deloma skriti, a stalni prenos vedenja je obstajal vse do časa, ko je teologija izgubila vodilno vlogo v akademskem svetu in je bila muzikologija priznana kot ena od znanstvenih disciplin.

Analiza besedil prikazuje, kateri elementi Praetoriusovega dela so postali del teoloških razprav o glasbi v zgodnjem novem veku v Nemčiji. Zasleduje prvotni pomen Syntagme musicum v smislu visoko znanstvenega organološkega besedila. Pastorji so ponavadi posvojili informacije o iznajdbi orgel in njihovem vstopu v cerkveno glasbo. Še posebno je bil vpliven Praetoriusov katalog takratnih orgel. Na podlagi njegovega zgleda so avtorji orgelskih pridig sami začeli v svojih besedilih navajati dispozicije novo postavljenih glasbil. Še posebej zanimivo pa je tudi povzemanje Praetoriusovega prevoda delov spisa Il Transilvano Girolama Dirute (Benetke, 1593). 